\title{
Małgorzata CHUDZIKOWSKA-WOŁOSZYN*
}

\section{RECEPCJA ŹRÓDEŁ ASCETYCZNYCH \\ I MONASTYCZNYCH W LIBER MANUALIS DHUODY Z SEPTYMANII (OK. 803-843)}

Podręcznik Dhuody z Septymanii zajmuje ważną i unikatową pozycję w odniesieniu do dziejów oraz rozwoju piśmiennictwa zwierciadłowego. Twórczość uczonych reprezentujących epokę tzw. odrodzenia karolińskiego ze szczególną intensywnością koncentrowała się na próbie zdefiniowania istoty oraz zadań chrześcijańskiego władcy, arystokraty, a także urzędnika. Był to okres, w którym możemy mówić o pełnym ukonstytuowaniu się parenetycznego gatunku speculum principis oraz speculum laicalis ${ }^{1}$. Licznie powstające wówczas zwierciadłowe podręczniki dla władców oraz możnych zawierały bezpośrednie napomnienia oscylujące wokół teorii państwa i społeczeństwa podążającego za biblijnym porządkiem. Zawarta w nich pareneza miała być uniwersalnym drogowskazem dobrego postępowania w odniesieniu do konkretnych i jak najbardziej realnych sytuacji ${ }^{2}$. Kluczowym elementem myśli politycznej, obecnej we wszystkich zwierciadłowych dziełach IX w., było augustyńskie wyobrażenie państwa Bożego. Wierzono, że na drodze moralnej reformy doczesna wspólnota ludzka może dostapić duchowego odnowienia. Należało więc przekonać władców, że ich status i pozycja nie jest wartością samą w sobie, ale misją i zobowiązaniem ${ }^{3}$. To oni bowiem - wespół z pozostałymi

${ }^{*}$ Dr Małgorzata Chudzikowska-Wołoszyn - adiunkt w Pracowni Historii Starożytnej i Kultury Antycznej, w Zakładzie Historii Starożytnej i Średniowiecznej, w Instytucie Historii i Stosunków Międzynarodowych Uniwersytetu Warmińsko-Mazurskiego w Olsztynie; e-mail: m.chudzikowska@uwm.edu.pl.

${ }^{1}$ Na temat zwierciadeł w okresie karolińskim zob. H.H. Anton, Fürstenspiegel und Herrscherethos in der Karolingerzeit, Bonn 1968; tenże, Fürstenspiegel des Frühen und Hohen Mittelalters, Darmstadt 2006, 3-19; W. Fałkowski, Karolińskie zwierciadło władcy-powstanie gatunku, w: Europa barbarica, Europa christiana, red. R. Michałowski, Warszawa 2008, 59-74.

${ }^{2}$ Wojciech Fałkowski (Karolińskie zwierciadło władcy, s. 65-66) wskazał na trzy nieodłączne i konieczne cechy dzieł z gatunku speculum principis, które pozwalają na odróżnienie ich od innych parenetycznych rozpraw i traktatów na temat władzy oraz państwa. Pierwszym warunkiem był dydaktyczny wymiar pracy, drugim - jej uniwersalny charakter, trzecia cecha wiązała się natomiast z praktycyzmem. Wskazówki miały odnosić się do realnych i namacalnych sytuacji. Autorzy przedstawiali w pełni znane sobie społeczeństwo, które pragnęli skierować na drogę zbawienia. Ideałem była oczywiście niebiańska civitas Dei.

${ }^{3}$ Do praktycznego wymiaru sprawowanej władzy oraz obowiązków spoczywających na królu 
dygnitarzami i możnowładcami - ponosili wzajemną odpowiedzialność za realizację planów Stwórcy w powszechnej wspólnocie chrześcijańskiej.

1. Kulisy powstania oraz adresat Podręcznika. Parenetyczne dzieło Dhuody - markizy Septymanii - powstało w latach 841-843. Był to okres niezwykle trudny w dziejach imperium karolińskiego. Zbudowana przez legendarnego Karola Wielkiego (ok. 747-814) polityczna jedność okazała się niestety, już w następnym pokoleniu, bytem kruchym i efemerycznym. Panowanie Ludwika Pobożnego (778-840) sprowadzało się do ciagłego zmagania z potencjalnymi rywalami w postaci nielojalnych kuzynów oraz zdradzieckiej magnaterii. Podręcznik frankońskiej arystokratki w pełni oddaje katastrofalną sytuację polityczną połowy IX wieku ${ }^{4}$ Rozdarte sporami dynastycznymi cesarstwo nie zapewniało bezpieczeństwa swoim poddanym. Rosnący w siłę wpływowi możni wybierali pogoń za chęcią zysku aniżeli rzeczywiste oddanie i wierność jedynemu monarsze. Silny i niepodważalny autorytet władcy uległ poważnemu nadszarpnięciu. W obliczu tak dalece posuniętej regresji, teologowie i doradcy królewscy nie ustawali w intelektualnych wysiłkach, które miały przynieść uzdrowienie monarchii. Komponując liczne dzieła, a pośród nich także dydaktyczne zwierciadła, starali się kreślić przed daleką od zdyscyplinowania arystokracją frankońską chrześcijańskie ideały etycznego postępowania.

Zwierciadło Dhuody pomimo tego, że nie odbiega w zakresie formy oraz podjętych wątków od innych parenetycznych dzieł tego okresu, zasługuje na miano zupełnie nietypowego i oryginalnego. W pierwszej kolejności należy podkreślić, że napisane zostało przez kobietę (niespotykane w dobie karolińskiej), o której historiografia milczy. Jedynym źródłem naszej wiedzy o autorce jest samo dzieło. Kolejnym aspektem wyróżniającym jest ton przyjętej przez arystokratkę narracji, który sprawia, że mamy do czynienia nie tylko z wzorcotwórczym traktatem odnoszącym się do

odniósł się już Izydor z Sewilli (ok. 560-636) w Etymologiach (Isidorus Hispalensis, Etymologiae IX 3, 1, PL 82, 341) podkreślając, że „królestwo wywodzi się od królów, a królowie nazywani są tak od królowania" (tłum. za: Fałkowski, Karolińskie zwierciadło władcy, s. 60). Ta myśl towarzyszyć będzie wszystkim wczesnośredniowiecznym utworom zwierciadłowym. Znajdziemy ją w spisanym w VII w. anonimowym irlandzkim traktacie De duodecim abusis saeculi, którym inspirował się także Alkuin pisząc swe listy napominające - litterae exhortatoriae, które stanowiły preludium zwierciadeł karolińskich.

${ }^{4}$ Panowanie Ludwika Pobożnego przyniosło spory o imperialną schedę, które toczyły się pomiędzy jego żyjącymi synami - Lotarem (795-855), Ludwikiem Niemieckim (804-876), Karolem Łysym (823-877) oraz wnukiem po zmarłym Pepinie Akwitańskim (797-838) - Pepinie II (823-864). Oliwy do ognia dodawał fakt, że spadkobiercy Ludwika pochodzili z dwóch matek. Najbardziej faworyzowanym w owym czasie był najmłodszy syn cesarza - Karol Łysy. Jego matką była kontrowersyjna i młodsza od władcy o prawie 30 lat - Judyta Bawarska (805-843), znienawidzona przez starszych synów Ludwika. Nieporozumienia między braćmi zaczęły narastać po roku 818, w którym cesarz Ludwik ogłosił Ordinatio imperii. 
chrześcijańskiego pojęcia moralności, państwa i sprawiedliwości. Utwór jest przede wszystkim duchowym testamentem i osobistym pożegnalnym listem przepełnionym matczyną troską i oczekiwaniami ${ }^{5}$. Nowatorski i niespotykany w pozostałych karolińskich zwierciadłach jest wreszcie adresat osobistego pisma Dhuody. Księżna Septymanii zredagowała je z myślą o swoim 15-letnim synu Wilhelmie (826-850) ${ }^{6}$, który - w założeniu autorki - miał pełnić ważne funkcje publiczne i wywierać realny wpływ na budowanie społecznego ładu ${ }^{7}$. Zadedykowanie swojego dzieła świeckiemu arystokracie sytuuje Podrecznik Wilhelma w grupie tzw. specula laicalis, czyli zwierciadeł pisanych z myślą o uprzywilejowanej grupie możnych. Ów podgatunek był zdecydowanie mniej popularny aniżeli typowe zwierciadła królewskie, czy książęce. O ile władców starano się uczyć przede wszystkim rządzenia państwem, o tyle arystokratów instruowano jak panować nad samym sobą .

${ }^{5}$ Dhuoda przystępując do komponowania dzieła była najprawdopodobniej dotknięta ciężką chorobą. Utworowi w każdym miejscu towarzyszy atmosfera nieuchronnej śmierci. Bezpośredni i emocjonalny ton narracji sprawiają, że zwierciadło markizy z Septymanii jest nie tylko typowym zwierciadłem dla świeckiego możnego - czyli speculum laicalis, przede wszystkim jest zwierciadłem matki dla syna. Karen Cherewatuk (Speculum matris: Duoda's Manual, „Florilegium” 10:1988-1991, 49-64) określiła wzorcotwórcze studium Dhuody mianem jedynego w swoim rodzaju - speculum matris. Por. K. Cherewatuk, Speculum matris: Duoda’s Manual, „Florilegium” 10 (1988-91) 49-64.

${ }^{6}$ Markiza Septymanii została rozłączona z synem Wilhelmem w 841 r. Małżonek Dhuody skandalista Bernard z Septymanii († 844) - zdecydował się zabrać starszego syna z rodzinnej posiadłości w Uzès (na południu Francji w rejonie Marchii Hiszpańskiej), aby móc czynnie włączyć się do politycznej walki o władzę. Arystokraci wzięli udział w rozstrzygającej bitwie cesarskich synów pod Fontenay-en-Puisaye (25 VI 841). Bernard opowiadając się po stronie Lotara i Pepina Akwitańskiego skazał siebie i swojego syna na przegraną. W akcie komendacji oddał zwycięskim władcom - Karolowi Łysemu i Ludwikowi Niemieckiemu - małoletniego Wilhelma jako zakładnika. W tym samym czasie polecił odebrać Dhuodzie drugiego z ich synów - nowonarodzonego Bernarda (841-886) - który opuszczał matkę jeszcze jako nieochrzczone dziecię (jego imienia, nadanego później przez ojca, Dhuoda nie poznała aż do swojej śmierci).

${ }^{7}$ Dzieło pisane było oczywiście także z myślą o młodszym synu Dhuody - Bernardzie. Matka kładła na Wilhelma obowiązek zaopiekowania się małoletnim bratem i przekazaniu mu nauk, które pozostawiła w podręczniku. Wiedziona była jednocześnie nadzieją, że jej dzieło pozyska uniwersalny rozgłos. W Podręczniku wielokrotnie mamy do czynienia ze świadomym zwracaniem się do szerokiego kręgu odbiorców - młodych arystokratów predestynowanych do pełnienia różnych funkcji państwowych. Karolińska autorka mogła mieć na myśli wszystkich młodocianych magnatów, którzy tak jak Wilhelm przebywali na dworze Karola Łysego, stanowiąc grupę tzw. przyszłych ministri króla. Jest także wielce prawdopodobne, że Dhuoda mogła głęboko ufać, iż jej książką zainteresują się, za sprawą samego Wilhelma, inni członkowie dworu i wreszcie także sam król. $\mathrm{Na}$ temat adresata utworu zob. J. Nelson, Gendering Courts in the Early Medieval West, w: Gender in the Early Medieval World. East and West, 300-900, ed. L. Brubaker - J.H.M. Smith, Cambridge 2004, 194-195. R. Le Jan, Dhuoda ou l'opportunité du discours féminin, w: Agire da donna. Modelli e pratiche di rappresentazione (secoli VI-X), ed. C. La Rocca, Turnhout 2007, 119.

${ }^{8}$ Por. J. Meyers, Dhuoda et la justice d'après son Liber Manualis (IX siècle), „Cachiers de Recherches Médiévales et Humanistes" 25 (2013) 452. 
2. Kompozycja zwierciadła Dhuody. W 11 księgach wzorcotwórczego traktatu karolińska uczona starała się zamknąć summę swojej wiedzy o otaczającym ją świecie, zarówno tym doczesnym, jak i ponadzmysłowym. Narracja Dhuody oparta została na licznych zapożyczeniach i inspiracjach. Liber manualis w pierwszej kolejności jest prawdziwą antologią cytatów biblijnych. Pod tym względem nie różni się bardzo od innych zwierciadeł doby karolińskiej, których podstawę stanowiły liczne pasaże ze Starego i Nowego Testamentu, ostatecznie zespolone nicią wprawnego komentarza. Ten szczegółowo dobrany materiał biblijny miał służyć edukacji intelektualnej, duchowej i moralnej.

Zwierciadło skomponowane dla Wilhelma ogółem zawiera ponad 600 odniesień do innych źródeł literackich. Dziewięćdziesiąt procent zgromadzonego materiału stanowią wspomniane już passusy biblijne (na 550 cytowań aż 200 odnosi się do Księgi Psalmów ${ }^{9}$ ). W pozostałych dziesięciu procentach odnajdziemy nawiązania do tradycji patrystycznej, pism monastycznych oraz - w śladowych ilościach - do literatury klasycznej. Zgromadzony przez karolińską autorkę materiał egzemplifikacyjny miał stanowić spójną chrześcijańską doktrynę na temat państwa, sprawiedliwości oraz obowiązków, tych społecznych, jak i politycznych, o których winien był dowiedzieć się młodociany Wilhelm. Przewodnią myślą interpretacyjną Dhuody było założenie, że wszelkie chrześcijańskie teksty należy czytać nie tylko ze zrozumieniem, ale co najważniejsze, umiejętnie wprowadzać je w życie. Matka wybrała dla Wilhelma te przykłady teologicznej i ascetycznej mądrości, które - w jej osobistej opinii - zapewniały rozwój duchowy i moralny. „Utkane” z wielorakich struktur dzieło autorka określiła jako contextus ${ }^{10}$. Uważała bowiem, że stanowi niezwykle korzystną osnowę wywodzącą się z różnorodnych ksiąg. Dhuoda podkreślała, że jej pisarskiemu trudowi nieustannie towarzyszyło patetyczne natchnienie (dignus affectus), dzięki któremu dobrała i połączyła wszystkie testimonia podług intelektualnych możliwości jej syna ${ }^{11}$.

Głównym celem niniejszego artykułu jest analiza źródeł monastycznych i ascetycznych, które wpłynęły na retorykę Liber manualis. Autorka podejmie próbę usystematyzowania zapożyczeń, które uczona karolińska cytowała bądź parafrazowała w swoim traktacie. Szczegółowa eksploracja wspomnianych passusów pozwoli określić metodę kompilacyjną oraz interpretacyjną, która

\footnotetext{
${ }^{9}$ Dla społeczeństwa karolińskiego Biblia miała ogromne znaczenie. Już nauka czytania na poziomie elementarnym odbywała się na drodze przepisywania i uczenia się na pamięć psałterza. Podstawy wiedzy o świecie pochodziły z ksiąg Starego Testamentu. Biblia dla pobożnych świeckich była więc zarówno elementarzem, jak i modlitewnikiem. Pełniła funkcję zarówno dokumentu religijnego, jak i historycznego. Była podręcznikiem gramatyki, słownikiem, poezją, a także dziełem propedeutycznym i parenetycznym. Por. F. Prinz, Niemcy - narodziny państwa. Celtowie, Rzymianie, Germanie, thum. D. Fałkowska, Warszawa 2007, 247.

${ }^{10}$ Połączenie, osnowa, ozdobny haft.

${ }^{11}$ Por. Dhuoda, Liber manualis Dhuodane quem ad filium suum transmisit Wilhelmum IX 1, ed. P. Riché, SCh 225, Paris 1997, 329: „ex diversis librorum voluminibus sit utiliter contextus, tamen eorum testimoniis secundum tuae qualitatis mensuram digno affectu inserere malui”.
} 
towarzyszyła wczesnośredniowiecznej uczonej. Dodatkowo także umożliwi postawienie kilku pytań badawczych, dotyczących formacji intelektualnej markizy z Uzès, jej dostępu do ksiag, świadomości twórczej oraz orientacji w zakresie zachodzących w państwie przemian polityczno-religijnych.

3. Formacja intelektualna autorki. Dhuoda z Septymanii reprezentowała uprzywilejowaną klasę tzw. laici religiosi. Świecka arystokracja epoki karolińskiej, obok księży i zakonników, jak najbardziej miała dostęp do uprawiania sztuk wyzwolonych i przyswajania sobie kultury. Do rozprzestrzeniania i dystrybucji wiedzy w państwie karolińskim niezwykle przyczyniały się licznie powstające od VIII w. szkoły przyklasztorne, diecezjalne oraz prezbiterialne. Bogaci możni zamawiali produkowane w skryptoriach woluminy, korzystali z dużych bibliotek klasztornych, upowszechniało się także coraz bardziej pożyczanie książek z ośrodków kościelnych ${ }^{12}$. Stopień wykształcenia świeckiej arystokracji był jednak znacznie zróżnicowany, niewątpliwie zależny od lokalnych tradycji, osobistych upodobań, zainteresowań i - wreszcie także - dostępu do dobrego nauczyciela ${ }^{13}$. Wiadomości o wychowaniu poszczególnych książąt merowińskich, jak i karolińskich, są niestety zbyt skąpe i nie pozwalają na ukonstytuowanie pewnego osądu. Jeszcze mniej informacji posiadamy na temat wykształcenia kobiet w okresie wczesnego średniowiecza. Erudycja Dhuody potwierdzać może tezę o powszechności edukacji i kultury zarówno w rodzinach książęcych, jak i pośród przedstawicieli arystokracji feudalnej. Dostęp do starannego wykształcenia oraz samodzielnego osądu w kwestiach intelektualnych miały więc również kobiety ${ }^{14}$.

Lista dzieł, do których odwoływała się arystokratka karolińska, niewątpliwie świadczy o jej oczytaniu, pragnieniu zdobywania wiedzy, a także orientacji na bieżące tematy polityczno-religijne w państwie. Z tekstu Podręcznika, który okazuje się niezwykle autobiograficzny w swej wymowie, wynika, że Dhuoda posiadała bibliotekę, bądź większy księgozbiór. W prologu do traktatu namawiała syna, aby z upodobaniem często czytał zadedykowany mu podręcznik, chociaż posiada wiele innych książek (być może tych pozostawionych mu w rodzinnym majątku przez matkę) ${ }^{15}$. W innym miejscu dzieła namawiała syna, aby powiększał bibliotekę i wciąż kupował woluminy ${ }^{16}$.

${ }^{12}$ Por. R. McKitterick, The Carolingians and the Written Word, New York, Cambridge 1989, 261-266.

${ }^{13}$ Por. E. Auerbach, Język literacki i jego odbiorcy w późnym antyku łacińskim i średniowieczu, thum. R. Urbański, Kraków 2006, 237.

${ }^{14}$ Por. tamże.

${ }^{15}$ Por. Dhuoda, Liber manualis, Prologus, SCh 225, 80: „Licet sint tibi multa adcrescentium librorum volumina, hoc opusculum meum tibi placeat frequenter legere”, „Nawet jeżeli posiadasz wiele ksiagg, niechaj miłym się dla ciebie stanie czytanie mojego dziełka". Tłumaczenia fragmentów Liber manualis przytoczonych $\mathrm{w}$ artykule pochodzą od autorki.

${ }^{16}$ Por. tamże I 7, SCh 225, 114: „Admoneo te etiam, o mi fili Wilhelme pulchre et amabilis, ut inter mundanas huius saeculi curas, plurima volumina librorum tibi adquiri non pigeas, ubi de Deo 
Ujawniała także swą bibliofilską naturę, kreśląc przed Wilhelmem poetycką metaforę świata jako ogromnego zwoju pergaminu, na którym pisarze próbują nakreślić wielkość Boga ${ }^{17}$.

4. Wpływ Reguly św. Benedykta na retorykę Liber Manualis. Analiza literatury chrześcijańskiej, której ślady i inspiracje odnajdujemy w moralnym poradniku dla Wilhelma, pozwala stwierdzić, że Dhuoda była pod silnym i dominującym wpływem źródeł ascetycznych i monastycznych. Ze szczególną atencją odnosiła się do Reguły świętego Benedykta. Aż w ośmiu fragmentach zwierciadłowego utworu odnajdujemy nawiązania do cenobijnych wskazówek, które - zdaniem karolińskiej autorki - stanowiły idealny drogowskaz także dla świeckiej części wspólnoty. Nie przytaczała ona jednak, co znamienne, tekstu Reguły literalnie. Raczej parafrazowała ją, co pozwala założyć, iż przywoływała wygodne dla siebie passusy z pamięci. Nie anonsowała także wprowadzanych do traktatu cytowań. Tylko w jednym miejscu pozwoliła sobie na zdawkowe określenie: ,zostało bowiem powiedziane”, po którym przywołała literalny fragment $\mathrm{z}$ ascetycznego zbioru.

Analizując drugą księgę Liber manualis odnajdujemy rozdział - $O$ poszanowaniu modlitwy ${ }^{18}$, którego tytuł mocno koresponduje z 20. rozdziałem Reguty świętego Benedykta ${ }^{19}$. Okazuje się, że admonicje Dhuody, w których kreśliła przed Wilhelmem siłę i znaczenie modlitwy wyraźnie zainspirowane zostały nauczaniem Benedykta z Nursji (ok. 480-547). Wiedziona jego refleksjami nie ustawała $\mathrm{w}$ zapewnianiu syna o przypisanych modlitwie cnotach, w których wytrwać powinien każdy gorliwy chrześcijanin. Osobistej adoracji powinny towarzyszyć bowiem obligatoryjna pokora, zwięzłość oraz cisza ${ }^{20}$.

creatori tuorum per sacratissimos doctorum magistros aliquid sentire et discere debeas, plura atque maiora quam supra scriptum est”, „Napominam cię mój synu Wilhelmie, piękny i ukochany, ażebyś pośród doczesnych trosk twojego pokolenia, nie zaniedbywał, ażeby pozyskiwać dla siebie liczne tomy ksiag; w nich powinieneś czytać o Bogu Stwórcy od najświętszych nauczycieli; będą one dostojniejsze i lepsze od tego, co zostało napisane powyżej (przeze mnie)".

${ }^{17}$ Por. tamże I 6, SCh 225, 110-112: „Certe, si polus et ardua in modum cartis membranae extensae per aera essent, et ponti concava interstinctis diversis firma mutata fuisse(n)t, atque ipsi orbi cultores cuncti, nascentes in mundum, ob ingenio humanitatis augmentum omnes fuissent scriptores, $[\ldots]$ comprehendi non valerent Omnipotentis magnitudinem [...] narrari”, „Bez wątpienia, gdyby niebo i pola zostały rozpostarte w powietrzu niczym zwój pergaminu, i gdyby zagłębienia mórz zmieniły się w plamy zabarwione na różne kolory, a wszyscy zamieszkujący i użytkujący tę ziemię, urodzeni na niej, w wyniku pomnożenia ludzkich zdolności staliby się pisarzami, [...] to jednak nie zdołaliby wyrazić wielkości wszechmogącego Boga".

${ }^{18}$ Por. tamże II 3: De reverentia orationis, SCh 225, 124.

${ }^{19}$ Por. Benedictus, Regula 20: De reverentia orationis, Die Benediktsregel (Lateinisch/Deutsch), ed. P.U. Faust, Stuttgart 2009, 74.

${ }^{20}$ Por. Dhuoda, Liber manualis II 3, SCh 225, 126: „Et si homini terreno potentiori nos aliquam utilitatem, magnam vel parvam, volumus petere ut det, non superbiendo nec in strepitu clamoris petimus murmurando, sed humiliando rogamus”, „Jeżeli chcemy, aby możnemu śmiertelnikowi dał (Bóg) jakąś korzyść, dużą lub małą, prosimy nie chełpiąc się, ani także hucząc w ferworze krzyku, 
Dhuoda wierzyła, że codzienna modlitwa jest przejawem nieodzownej potrzeby kontemplacji Boga. Namawiała Wilhelma do ciagłej i żarliwej modlitwy ${ }^{21}$, która miała dla niej wymiar mistyczny i medytacyjny. Podręcznik jest pierwszym tak osobistym świadectwem dojrzałej świeckiej duchowości. Dar modlitwy, który autorka pielęgnowała i rozwijała w swych katechetycznych rozważaniach pozostawał w bliskiej korelacji z Reguła mnicha z Nursji. Benedykt jednak, co należy podkreślić, formułując wskazania dotyczące doskonalenia modlitwy obficie korzystał z doświadczenia innych mistrzów ascezy. Szczególnie inspirujący był dla niego Jan Kasjan (ok. 360-433) 22 .

Nie ulega wątpliwości, że ascetyczne reguły pełniły w kontemplacyjnej narracji Dhuody rolę religijnego paradygmatu. Autorka jednak pozwalała sobie niekiedy pogłębiać mądrość Ojców i wprowadzać dość oryginalne continuum do ich nauczania. Dzieje się tak w przypadku jej rozważań wokół znaczenia i miejsca modlitwy, do których dołączyła osobiste refleksje i aluzje. Uważała bowiem, że do prawdziwej wiary prowadzi trzystopniowy proces laudacyjny. Rozpoczynał się on od ust (chodziło o czytanie i wypowiadanie słów Bożych), dalej rozwijał się w sercu (w wyniku głębokiej kontemplacji i zrozumienia),

lecz modlimy się w pokorze”; Benedictus, Regula 20, 1-2, ed. Faust, s. 74: „Si, cum hominibus potentibus volumus aliqua suggerere, non praesumus nisi cum humilitate et reverentia, quanto magis domino deo universorum cum omni humilitate et puritatis devotione supplicandum est", thum. A. Świderkówna: Święty Benedykt z Nursji, Reguła, Kraków 2010, 56: „Jeżeli ludziom możnym pragniemy przedstawić jakąśs sprawę, ośmielamy się czynić to jedynie z najgłębszą pokorą i szacunkiem. Z o ileż większą pokorą i czystszym oddaniem musimy zanosić nasze prośby przed oblicze Boga, Pana wszechświata!”. Por. także Dhuoda, Liber manualis II 3, SCh 225, 126: „Non in voce clamosa nec in longa pertrahendi verba, sed in summo et brevi affectu cum silentio quaerendum est”, „Nie należy (Go) szukać za pomocą hałaśliwego głosu, ani rozwlekać się w długich słowach, lecz za pomocą szczególnej i krótkiej żarliwości”; Benedictus, Regula 20, 4, ed. Faust, s. 76: „Et ideo brevis debet esse et pura oratio, nisi forte ex affectu inspirationis divinae gratiae protendatur", tłum. Świderkówna, s. 56: „Dlatego też modlitwa powinna być krótka i czysta, chyba że natchnienie łaski Bożej skłoni nas do jej przedłużenia”. Zob. tamże 52, 4, ed. Faust, s. 124: „simplicer intret et oret, non in clamosa voce, sed in lacrimis et intentione cordis”, thum. Świderkówna, s. 86: „niech wejdzie po prostu i niech się modli, nie na cały głos, lecz ze łzami i z głębi serca”.

${ }^{21}$ Por. Dhuoda, Liber manualis VIII 1, SCh 225, 306: „De hoc adhortor, ut in lectione et oratione dignissima sensus tuus vigil et promptus semperque purus adsistat et mundus. Lege et ora ut Exauditor omnium aurem suum dignetur acomodare tibi”, „O tym przypominam, aby rozum twój zawsze trwał w czcigodnej lekturze i w modlitwie czuwający, gotowy i czysty. Czytaj i módl się, aby Ten, który wysłuchuje wszystkich zechciał przychylić ku tobie swego ucha”.

${ }^{22}$ Por. H. Dybski, Modlitwa w ujęciu Jana Kasjana, VoxP 19 (1999) t. 36-37, 335. Benedykt wspominał dzieło Jana Kasjana w 73. rozdziale Reguły. Zob. Benedictus, Regula 73, 4-6, ed. Faust, s. 168: „Aut quis liber sanctorum catholicorum patrum hoc non resonat, ut recto cursu perveniamus ad creatorem nostrum? Necnon et collationes patrum et instituta et vitas eorum, sed et regula sancti patris nostri Basilii, quid aliud sunt nisi bene viventium et oboedientium monachorum instrumenta virtutum?”, thum. Świderkówna, s. 113-114: „A któraż księga świętych katolickich Ojców nie przynosi wyraźnych pouczeń, w jaki sposób mamy prostą drogą dążyć do naszego Stwórcy? Czymże są i «Konferencje» Ojców i «Ustawy», i ich żywoty, czymże Reguła św. ojca naszego Bazylego, jeśli nie narzędziami, z których pomocą mnisi, dobrzy i posłuszni, budują swoje cnoty?” 
kończył zaś i dopełniał na uczynkach ${ }^{23}$. Ostatni z etapów modlitewnych stanowi osobistą interpretację Dhuody. Medytacja, jej zdaniem, miała prowadzić nie tylko do zrozumienia Boga, ale także - w wyniku dobrych i słusznych uczynków - do współuczestniczenia w boskiej rzeczywistości. Święty tekst zawierał, zdaniem autorki, nie tylko słowa mówiące o Bogu, przede wszystkim uobecniał Bożą moc, która cierpliwych chrześcijan prowadziła do zbawienia. Jego pełne znaczenie, co podkreślała uczona, nie objawiało się jedynie tylko w wyniku samotnego studiowania (które było pierwszym krokiem ważnego procesu medytacji), ale ponad wszystko dokonywało się poprzez nałogowe wręcz wprowadzanie w praktykę tego, co przeczytane ${ }^{24}$.

Do cenobijnych zasad odwoływała się Dhuoda nie tylko w odniesieniu do rozważań nad samą istotą modlitwy, ale szukała w nich także wzorców codziennego postępowania oraz wskazówek, które mogłyby okazać się skuteczne dla dorastającego młodego arystokraty. Reguła świętego Benedykta pojawia się w księdze trzeciej poświęconej powinnościom, które Wilhelm winien był okazywać względem ojca, króla i duchownych. Autorka w następujących po sobie rozdziałach i podejmowanych w nich zagadnieniach symbolicznie zarysowywała przed synem naturalną hierarchię bytów oraz należnych im rewerencji. Pokora, szacunek i lojalność względem ojca rodu była jej zdaniem obowiązkiem, który bezwzględnie spoczywał na synach przez całe ich życie ${ }^{25}$. W pierwszej kolejności powinni okazywać cześć Bogu, później własnemu ojcu, następnie władcy i kolejno także duchownym.

Wierność ojcu oznaczała - zgodnie z feudalnym zwyczajem - wierność rodzinie. Wzmacnianiu solidarności rodowej, zdaniem Dhuody, powinny nieustannie towarzyszyć słowa św. Benedykta, który uważał, że wspólnota dostąpi pokoju tylko wtedy, jeśli obce jej będzie „,szemranie, w jakiejkolwiek

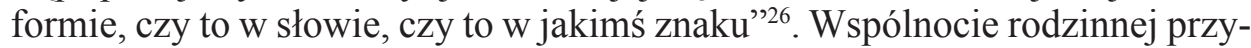
dała więc autorka charakter wspólnoty klasztornej. I tak jak Benedykt z Nursji

${ }^{23}$ Por. Dhuoda, Liber manualis II 3, SCh 225, 128: „Ora ore, clama corde, roga opere”, „Módl się wypowiadanym słowem, krzycz swym sercem, upraszaj działaniem"; tamże I 5, SCh 225, 106: „Hoc te admoneo ut et in virtutes, et in elementa, et in corporis sensus, dicta sanctorum evangeliorum, cum aliorum documenta Patrum in tua semper revolvas mente”, „Przypominam ci to, abyś zawsze w swoim umyśle, odnosząc się do cnót, substancji i zmysłów ciała, analizował słowa świętych ewangelistów wraz ze świadectwami innych Ojców, tak abyś wierzył myśleniem, mówieniem i działaniem"; tamże II 2, SCh 225, 124: „A quo bona cuncta speras accipere, quaere cogitando, pete loquendo, pulsa operando. Haec tria agendo, ad summam et perfectam venies, quae dicitur karitas", „Oczekujesz, że otrzymasz od Niego liczne dobra, szukaj więc myślami, proś w słowach, pobudzaj działaniem. Czynieniem tych trzech, dojdziesz do najważniejszej i doskonałej cnoty, którą określa się miłością".

${ }^{24}$ Por. M.A. Mayeski, Dhuoda. Ninth Century Mother and Theologian, Scranton 1995, 53.

${ }^{25}$ Por. Dhuoda, Liber manualis III 1, SCh 225, 134: „De reverentia patris, quam dum vivis agere debes".

${ }^{26}$ Benedictus, Regula 34, 6, ed. Faust, s. 94: „Ante omnia, ne murmurationis malum pro qualicumque causa in aliquo qualicumque verbo vel significatione appereat", thum. Świderkówna, s. 67. 
wierzyła, że idealne relacje między członkami tej samej familii mogły ujawnić świadectwo obecności Boga, który zsyłał na nią pokój ${ }^{27}$. Struktura rodzinna, w ujęciu karolińskiej pisarki, stanowiła więc obok struktury zakonnej przestrzeń, w której ujawniało się i realizowało powszechne panowanie Chrystusa.

Martin Claussen podkreślił, że Dhuoda pisząc swój podręcznik świadomie przyjęła na siebie autorytatywną i jednocześnie „,naprawczą” rolę opata. Sięgnęła do klasztornego ideału correctio - obowiązku, który spoczywał na zwierzchniku zakonnym, aby prostować zachowanie młodszych i kształcących się mnichów ${ }^{28}$. Czuła się w pełni uprawnioną do tego, aby przypisać sobie autorytet opata ${ }^{29}$. Pomimo świadomości posiadania „słabszej płci”,30, pewności dodawała jej rola matki i wychowawczyni oraz idąca za nimi misja przekazania synowi pobożnych ideałów. Model edukacyjny, który przejęła na siebie markiza z Uzès, nosi znamiona monastycznych reform, które Ludwik Pobożny podjął na dwóch synodach w Akwizgranie (816 i 817). W zatwierdzonych dekretałach odnajdujemy zapisy dotyczące odpowiedniego nauczania w klasztorach. Na zakonnych nauczycieli nałożony został obowiązek objęcia uczniów szczególną troską i starannością ${ }^{31}$.

Karolińska arystokratka $\mathrm{w}$ wielu miejscach podręcznika przekazywała synowi silną świadomość godności oraz rangi rodu, z którego wywodził się jego ojciec. Liber manualis ukształtowany został na kanwie arystokratycznej

${ }^{27}$ Por. Dhuoda, Liber manualis III 1, SCh 225, 138: „Quisquis considerat ista volensque ista, consideret et illa ut si quod supra, et tunc omnia membra utiliter vertuntur in pace”, „Każdy kto tak uważa i tych chce, niech weźmie pod uwagę i te, które były wcześniej, a także i to, że: wszyscy członkowie pożytecznie żyją w pokoju”; Benedictus, Regula 34, 5, ed. Faust, s. 94: „et ita omnia membra erunt in pace”, thum. Świderkówna, s. 67: „I w ten sposób wszyscy będą w pokoju”.

${ }^{28}$ Por. Benedictus, Regula 2, 23-24, ed. Faust, s. 26: „In doctrina sua namque abbas apostolicam debet illam semper formam servare, in qua dicit: Argue, obsecra, increpa. Id est miscens temporibus tempora, terroribus blandimenta, dirum magistri, pium patris ostendat affectum", thum. Świderkówna, s. 26: „Jako nauczyciel powinien opat trzymać się zawsze tej oto zasady Apostoła: «Przekonywaj, proś, karć!» (2Tm 4, 2 Wlg), to znaczy stosownie do czasu i okoliczności łączyć surowość z łagodnością, okazując się raz wymagającym mistrzem, to znowu pełnym miłości ojcem”.

${ }^{29}$ Por. M.A. Claussen, Fathers of Power and Mothers of Authority: Dhuoda and the Liber manualis, „French Historical Studies” 19 (1996) nr 3, 800.

${ }^{30}$ Wielokrotnie mówi o swojej słabości i kobiecej ułomności: Dhuoda, Liber manualis I 4, SCh 225, 104: „Adhuc, quanquam fragilis ad umbram”, „I chociaż ciagle jestem słaba niczym cień”; tamże Prologus, SCh 225, 80: „Multis plura patent, mihi tamen latent, meae quoque similes, obscurato sensu”, „Brakuje mi zrozumienia dla wielu oczywistych spraw, które pozostają dla mnie wciąż nieodkryte”; tamże: „Dhuoda quanquam in fragili sexu”, „Ja Dhuoda reprezentuję słabą płeć”; tamże II 3, SCh 225, 126: „Ego autem Dhuoda tepida et desidiosa fragilisque et declinans semper ad ima”, „Ale ja Dhuoda (jestem) słaba, ospała i niepewna, i zawsze kieruję się w otchłań”; tamże Praefatio, SCh 225, 86: „secundum parvitatis meae intelligentiam”, „,na miarę małości mego rozumu”.

${ }^{31}$ Por. Institutio sanctimonialium Aquisgranensis (816), can. 22, ed. A. Werminghoff, MGH, Concilia 2/1, Hannover 1908, 452: „Ut erga puellas in monasteriis erudiendas magna adhibeatur diligentia. Religio ecclesiastica docet, ut puellae, quae in monasteriis erudiuntur, cum omni pietatis affectu et vigilantissimae curae studio nutriantur, ne, si lubicae aetatis annos indisciplinate vivendo transegerint, aut vix aut nullatenus corrigi postea possint". 
tradycji, tę warstwę społeczną więc nieustannie gloryfikował ${ }^{32}$. Markiza Septymanii nie miała wątpliwości, że jej syn będzie miał realny wpływ na rządzenie państwem. Podręcznik miał przygotować go na pełnienie funkcji doradcy króla. Obowiązek służenia radą, zaraz po wiernym oddaniu władcy, stanowił główne zadanie arystokraty. On sam także powinien mieć wzgląd na opinię swoich doradców ${ }^{33}$. Podobnie każdy opat powinien wysłuchać i rozważyć, co mają do powiedzenia jego współbracia ${ }^{34}$. W pouczeniach na temat odpowiedzialnego służenia rada, które Dhuoda kieruje do syna, ponownie daje o sobie znać znajomość Reguły Benedyktyńskiej. Po raz kolejny więc autorka próbuje utworzyć paralelę pomiędzy formacją młodego oblata i dorastającego świeckiego arystokraty.

Monastyczne ideały wywarły również wpływ na retorykę czwartej księgi Liber manualis, która poświęcona została przywarom i cnotom doczesnego życia. Otwierają ją rozważania na temat istoty człowieczeństwa i jego miary. Pośród najważniejszych wad, które zagrażały sile i jedności możnych, arystokratka wymieniała ukrytą złośliwość i zazdrość. Nawet ci uchodzący za szczerze współczujących, jej zdaniem, mogli być fałszywi i obłudni. Tych należało się wystrzegać i jawnie występować przeciwko nim ${ }^{35}$. Wzorem pocieszenia oraz wspaniałomyślności był dla karolińskiej uczonej znany z Reguły Benedyktyńskiej mądry i doświadczony mnich - sympekt. Po określenie greckiego pochodzenia - sinpectas - sięgnęła Dhuoda przy okazji upomnień dotyczących dwulicowości świeckich dostojników. Przy jego pomocy nakreśliła zręczny oksymoron, który pozwolił zaakcentować rozmiar grzesznej hipokryzji dostojników. Pouczała Wilhelma, że nawet ci, którzy wyróżniają się szczerym współczuciem bliskim temu, które cechuje benedyktyńskich sympektów, mogą niestety kierować się tylko faryzejską przewrotnością ${ }^{36}$.

${ }^{32}$ Por. J. Ryś, Wychowanie moralne $w$ rodzinie arystokratycznej $w$ czasach karolińskich w świetle Podręcznika dla syna Dhuody, „Rocznik Naukowo-Dydaktyczny WSP w Krakowie” (1999) z. 201, 17.

${ }^{33}$ Por. Dhuoda, Liber manualis III 4, SCh 225, 152: „Fac cum consilio illorum qui tibi ad corpus et animam fidelem praeparent actionem. Scriptum est: «Omnia fac cum consilio, et post factum non paenitebis»”, „Działaj przy współudziale rady tych, którzy podpowiadają działania godne zaufania tak dla ciała, jak i dla duszy. Zostało napisane: «Wszystko czyń wraz z zastanowieniem, a nie będziesz żałował swego czynu»".

${ }^{34}$ Por. Benedictus, Regula 3, 2, ed. Faust, s. 30: „Et audiens consilium fratrum tractet apud se et, quod utilius iudicaverit, faciat”, tłum. Świderkówna, s. 28: „Wysłuchawszy opinii braci, niech ją sam rozważy, a następnie zrobi to, co jest lepsze”; tamże 3, 13, ed. Faust, s. 32: „sicut scriptum est: «Omnia fac cum consilio et post factum non paeniteveris»”, tłum. Świderkówna, s. 29-30: „«Nic nie czyń bez rady, a po uczynku nie będziesz żałował» (Prz 31, 3 Wlg; Syr 32, 24 Wlg).

${ }^{35}$ Por. Dhuoda, Liber manualis IV 1, SCh 225, 198: „et non solum contra saeculares, ob invidiae facibus exardescentes, expugnandum est, verum etiam, ut ait Apostolus, «contra spiritualia nequitiae, in caelestibus»”, ,i to nie tylko przeciwko ludziom świeckim, ze względu na to, że pałają płomieniem niechęci, zaprawdę także należy występować, jak rzecze apostoł «przeciw pierwiastkom duchowym zła na wyżynach niebieskich»".

${ }^{36}$ Por. tamże IV 1, SCh 225, 198: „Sunt enim quasi florentes in saeculo et in rebus locupletes; 
Wspomnianą czwartą księgę zamyka wykład poświęcony wspieraniu ubogich, chorych i głodnych. O uczynku tym w sposób szczególny, zdaniem autorki, pamiętać powinni ci, którzy tak jak Wilhelm, byli szlachetnie urodzeni, dostapili urzędów, godności oraz bogactw. Przekonywała syna, żeby zawsze pozostawał wrażliwy na prośby nędzarzy i nigdy nie ignorował ich niedostatku. Ludzkiego nieszczęścia nie należało także wyszydzać. Dla wzmocnienia swych dydaktycznych admonicji po raz kolejny Dhuoda powołała się na autorytet Reguły świętego Benedykta. Tym razem jednak wyraźnie wydzieliła cytowany passus z toku swojej narracji. Literalnie przytoczoną treść zapowiedziała następującymi słowami:

„Zostało powiedziane o nieszczęściach: «To czego nie chcesz dla siebie, drugiemu obyś nie czynił»" ${ }^{\text {37. }}$.

Cenobijne wskazówki patriarchy z Nursji traktowane były przez karolińską uczoną z jednej strony jako wzór religijnego życia, z drugiej jako remedium na wszelkie doczesne strapienia. Cała piąta księga Podręcznika koncentrowała się na prezentacji brzemion, które zagrażały ludziom. Pośród nich pojawiały się: smutek, zwodnicze bogactwo, prześladowania, pokusy, bieda, cierpienia, niebezpieczeństwa i - wreszcie także - liczne choroby. Zamykając księgę, niejako ku pokrzepieniu, Dhuoda apelowała do swego pierworodnego syna, aby nigdy nie poddawał się żadnym przeciwnościom i nie pokazywał $\mathrm{z}$ ich powodu smutku ${ }^{38}$. O ile zaś Bóg obdarzy go zdrowiem ciała niechaj pozwoli, aby ono służyło mu do zdrowego prowadzenia swej duszy ${ }^{39}$. Odpowiedzi na wszystkie pytania miał wreszcie szukać w Regule, do czego stanowczo nakłaniała go matka ${ }^{40}$.

attamen ex occulta malitia alios invidere atque dilaniare, prout valent, non cessant, et hoc per sinpectas”, „Są bowiem tacy jak gdyby znakomici w doczesnym życiu i zasobni w wiele rzeczy, jednakże oni ze swej ukrytej złośliwości zazdroszczą innym, jak tylko mogą, i nie poprzestają, ażeby dręczyć, i to nie jakoby na drodze współczucia". Sympekci - podnoszący na duchu starzy i mądrzy mnisi zostali wymienieni w 27. rozdziale Reguty Benedykta. Zob. Benedictus, Regula 27, 2-3, ed. Faust, s. 82: „Et ideo uti debet omni modo ut sapiens medicus inmittere senpectas, id est seniores sapientes fratres, qui quasi secrete consolentur fratrem fluctuantem”, tłum. Świderkówna, s. 61: „Tak więc musi, jak mądry lekarz używać najróżniejszych sposobów: Niechaj posyła do nich sympektów, tzn. starszych i mądrych mnichów, którzy by chwiejnego brata dyskretnie podnosili na duchu".

${ }^{37}$ Dhuoda, Liber manualis IV 9, SCh 225, 256: „Dictum est de iniuriis: «Quod tibi non vis, alii ne feceris»”. Święty Benedykt tę samą maksymę zawarł w 61. rozdziale Reguły. Por. Benedictus, Regula 61, 14, ed. Faust, s. 146: „quia scriptum est: Quod tibi non vis fieri, alio ne feceris”, thum. Świderkówna, s. 100: „Jest bowiem napisane: «Nie czyń drugiemu, co tobie niemiłe»”.

${ }^{38}$ Por. Dhuoda, Liber manualis V 8, SCh 225, 278: „Si infirmitas tuo accesserit corpori, noli deficere nec tristis ex ea incedas”, „Jeśliby w twoim ciele pojawiła się choroba, nie upadnij (nie poddawaj się jej) ani nie pokazuj smutku z jej powodu".

${ }^{39}$ Por. tamże V 8, SCh 225, 282-284: „Et si tibi Deus Prolixam iusserit dari sanitatem, rogo et ortor atque utiliter admoneo ut sanitatem corporis ad salutem iugiter perducaris animae”, „A jeśli tobie Bóg poleciłby, żeby dać zdrowie, proszę i błagam, a także pożytecznie napominam, abyś zawsze prowadził zdrowie ciała ku zdrowiu duszy".

${ }^{40}$ Por. tamże V 8, SCh 225, 284: „Lege «Curam pastoralem» et invenies”, „Czytaj Regułę zakonną a znajdziesz". 
Należy stwierdzić, że zainteresowanie Dhuody Reguła benedyktyńskq niewątpliwie wiązało się z przeprowadzoną przez Ludwika Pobożnego reformą życia monastycznego, któremu poświęcone były dwa synody z 816 i 817 r. pod przewodnictwem Benedykta z Aniane (747-821). Dotyczyły one przede wszystkim ujednolicenia przepisów regulujących życie wspólnot. Chodziło o wprowadzenie we wszystkich klasztorach frankońskich jednego modelu cenobijnego opartego na Regule św. Benedykta. Cesarz Ludwik przejawiał silne przywiązanie do wartości monastycznych. W normach spisanych przez mnicha z Nursji widział wzorzec sprawowania władzy królewskiej ${ }^{41}$. Nie ulega wątpliwości, że w dydaktycznych admonicjach Dhuody obserwujemy bardzo podobny sposób interpretacji Reguły na potrzeby życia i działalności świeckich możnych. Księżna wyszukiwała w niej niezbędne wskazówki moralne, duchowe i przywódcze, którymi miał kierować się jej syn.

Pojawia się oczywiście pytanie - skąd u Dhuody, kobiety reprezentującej stan świecki, taka wrażliwość na Regułę benedyktyńska, która właściwie była tekstem specjalistycznym, skierowanym tylko do duchownych i nie wychodzącym poza te kręgi. Co więcej, markiza Septymanii udowadnia wnikliwą znajomość owego źródła, a także umiejętność jego interpretacji w duchu instytucjonalnym i świeckim, która ściśle korelowała z debatą religijną w państwie. Osobą łączącą Dhuodę z wartościami i źródłami monastycznymi może być jej teść. Ojciec Bernarda - Wilhelm z Gellone (ok. 745-812) po okresie walecznej i oddanej służby rycerskiej ${ }^{42}$ zdecydował o poświęceniu się duchowości. W 804 r. założył klasztor w Gellone (w pobliżu Aniane, niedaleko Uzès) i pełnił w nim posługi świeckiego brata. Jego zwierzchnikiem był sam Benedykt z Aniane, reformujący w niedalekiej przyszłości Kościół karoliński. Dhuoda poślubiła Bernarda w 824 r., czyli już po reformie zakonnej oraz upowszechnianiu Reguły. Rodzina, w której się znalazła, miała więc silny związek z życiem klasztornym, jak i samym zreformowanym monastycyzmem. Tak więc zupełnie prawdopodobne jest to, że matka Wilhelma miała dostęp do tekstu Reguły. Znała ją na tyle dobrze, by cytować i powoływać się na nią w taki sam sposób, jak robiła to z materiałem biblijnym. Rzadko stosowała dosłowne przytoczenia. Bardziej zdawała się być natchnioną benedyktyńskim językiem, myślą i obrazem ${ }^{43}$.

5. Rola i sytuowanie ascezy Juliana Pomeriusza w religijnej pedagogice Dhuody. Można założyć hipotezę, iż to za sprawą spuścizny po włączonym do wspólnoty religijnej Wilhelmie mogła Dhuoda znać także pozostałe z dzieł ascetycznych, które parafrazowała bądź przytaczała w Liber manualis. W ad-

\footnotetext{
${ }^{41}$ Por. R. McKitterick, Królestwa Karolingów - władza, konflikty, kultura, thum. B. Hlebowicz - M. Wilk, Warszawa 2013, 151.

${ }^{42}$ Wilhelm był rycerzem Karola Wielkiego. Chronił akwitańską granicę imperium przed najazdami muzułmanów.

${ }^{43}$ Por. Claussen, Fathers of Power and Mothers of Authority, s. 795.
} 
monicjach skierowanych do Wilhelma znajdujemy wyraźne echo nauczania Juliana Pomeriusza (V/VI w.) i jego traktatu - De vita contemplativa $(O \dot{z} y$ ciu kontemplacyjnym), który napisany został na początku VI w. Tekst wywarł ogromny wpływ na późniejszą naukę ascetyczną średniowiecza i znajdował się praktycznie we wszystkich bibliotekach klasztornych Cesarstwa Karolińskiego ${ }^{44}$. Wizja duchowości, którą proponował Pomeriusz, była z pewnościa adresowana do duszpasterzy. Jednak duchowość ta, tak mocno inspirowana pierwiastkami monastycznymi, znajdowała w VIII i IX w. wielu zwolenników. Jako napisaną dla wszystkich chrześcijan traktowano szczególnie trzecią księge De vita contemplativa, która przypominała swym charakterem typowy traktat zwierciadłowy. Prezentowała katalog wad, których powinno się unikać, oraz listę cnót, których praktykowanie prowadziło do zdobycia pełni doskonałości chrześcijańskiej.

W dwóch miejscach Podręcznika dla Wilhelma refleksje Dhuody zdają się silnie korespondować z poglądami Pomeriusza. Rozdział 11. trzeciej księgi poświęcony został bezwzględnemu - zdaniem arystokratki - poszanowaniu kapłanów. Upominała swego szesnastoletniego syna, aby darzył duszpasterzy uniżonym uwielbieniem i szacunkiem. Chcąc oddać istotę zadań oraz funkcji, które pełnili słudzy ołtarza, przytoczyła wiele metaforycznych określeń. Być może w nawiązaniu do De vita contemplativa porównała duchownych do pomocników, wyznawców i wybrańców Boga ${ }^{45}$. Podobnie także do Pomeriusza wychwalała przymioty kapłanów i nazywała ich następcami apostołów włączonymi do wspólnoty świętych ${ }^{46}$.

Bezpośrednio do zaleceń zawartych w traktacie $O \dot{z} y c i u$ kontemplacyjnym księżna Septymanii odwołała się natomiast w księdze czwartej Liber manualis. Dokładnie w 8. rozdziale wspomnianej księgi zaprezentowała przed synem katalog chrześcijańskich cnót. Przekonywała go, aby nieustannie realizował je w swoim życiu. Świeccy arystokraci powinni sprzyjać sprawiedliwości i orze-

${ }^{44}$ Dzieło zachowane w prawie 90 rękopisach. Do najwcześniejszych manuskryptów zawierających De vita contemplativa należy jeden pochodzący z hiszpańskiego miasta León (datowany na przełom VIII i IX w.) oraz dwa rękopisy z Montpellier (powstałe w IX w.), miasta znajdującego się na południu Francji. Por. M. Thiebaux, Dhuoda, Handbook for her Warrior Son. Liber Manualis, Cambridge 1998, 261.

${ }^{45}$ Por. Dhuoda, Liber manualis III 11, SCh 225, 194: „Tu ergo, fili Wilhelme, venera eos, ut praedixi, dignis Deo famulantium sacerdotes. Dei enim sunt sortes, Dei adiutores cultoresque”, „Tak więc, synu Wilhelmie, czcij ich, jak wcześniej już powiedziałam, szacownych kapłanów, sługi Boże. Są bowiem pomocnikami, wyznawcami i wybrańcami Boga"; Julianus Pomerius, De vita contemplativa I 25, PL 59, 440: „Isti sunt ministri verbi, adjutores Dei, oraculum Spiritus sancti”, tłum. A. Żurek: Julian Pomeriusz, O życiu kontemplacyjnym, ŹM 17, Kraków 1998, 127: „Oni są sługami słowa, pomocnikami Boga, wyrocznią Ducha Świętego".

${ }^{46}$ Por. Dhuoda, Liber manualis III 11, SCh 225, 190-192: „Ipsi sunt in exemplo sanctorum Apostolorum [...] cum Sanctorum consortio iuncti"; Julianus Pomerius, De vita contemplativa I 25, PL 59, 440: „Isti sunt apostolorum Domini successores [...] Deo suo inseparabiliter adhaerentes”, ŹM 17, 127: „Oni, jako następcy apostołów [...] Oni to nierozerwalnie przynależą do Boga”. 
kać to, co słuszne ${ }^{47}$. Powinni także, w opinii karolińskiej uczonej, uciekać od bezprawia i reagować na każdą niegodziwość. Pobłażając okrucieństwu i fałszowi, zgadzają się na nie ${ }^{48}$. Jak czytamy bowiem w Liber manualis:

„Ktoś bowiem mówi [Dhuoda miała tu na myśli oczywiście Pomeriusza przyp. M. Ch.-W.]: «Grzeszę ze wszystkimi popełniającymi grzechy, gdy sam nie zmuszę do poprawy grzesznych, których zobaczę»" ${ }^{\prime 4}$.

Przywoływany przez autorkę fragment pochodził z trzeciej księgi De vita contemplativa, w której Pomeriusz przedstawił swoją koncepcję cnót i wad. Do ściśle ascetycznych wskazań znajdujących się w pierwszych dwóch księgach, dołączył on również tekst o charakterze duszpasterskim i moralnym, w którym Dhuoda znalazła aktualne dla siebie źródło inspiracji. Należy podkreślić także, że w zredagowanych dekretałach synodalnych z 816 r. - prócz odwołań do tekstu Benedicti regula - znajduje się również wiele wypisów ze wzmiankowanego już De vita contemplativa Juliana Pomeriusza ${ }^{50}$. Dzieła te traktowano niewatpliwie jako ważną podstawę źródłową służącą zredagowaniu przepisów, które uregulować miały życie wspólnot na terenie całego państwa frankońskiego. Można założyć więc hipotezę, że karolińska uczona miała styczność z dekretałami i znała ich treść. Być może także jedynie za pośrednictwem dokumentów synodalnych zetknęła się z fragmentami ascetycznego traktatu De vita contemplativa.

6. Punkty styczne między Regula świętego Augustyna a Podręcznikiem markizy z Uzès. W sferze domysłów pozostaje także orientacja uczonej w zakresie Reguty świętego Augustyna, która we wczesnym średniowieczu przeżywała niewątpliwe odrodzenie. Braki źródłowe powodują niestety spore

${ }^{47}$ Por. Dhuoda, Liber manualis IV 8, SCh 225, 244: „Dilige iustitiam, ut iustus esse videaris in causis”, „Sprzyjaj sprawiedliwości, abyś wydał się, że jesteś sprawiedliwym w kwestiach prawnych”.

${ }^{48}$ Por. tamże IV 8, SCh 225, 244: „Absit a te ut, pro caducis concupiscentiarum rerum, animam quam verus et mundus et veram et mundam atque immortalem in tuo misit fragilis corpore manentem, tu, ob iniustitiis et inmisericordiis aliquid iniuste componendo, dictando etiam et consentiendo, illa laqueis praepares malis”, „Niech ci się to nie zdarzy, że w silnym pragnieniu rzeczy chylących się ku upadkowi, gdy Ów prawdziwy i czysty umieści w twoim kruchym ciele duszę trwająca, która jest równie prawdziwa i czysta, a także nieśmiertelna, ty z powodu ustanawiania, mówienia i zgadzania się na pewne czyny niesłuszne i okrutne szykujesz dla tej (duszy) występne kajdany".

${ }^{49}$ Tamże IV 8, SCh 225, 246: „Dicit enim quidam: «Cum omnibus peccantibus pecco, si quos videro peccantes ipse non corrigam". Por. Julianus Pomerius, De vita contemplativa III 23, PL 59, 506: „quia si peccantem video, et non solum non arguo, sed etiam ei peccanti consentio, participem me damnationis eius efficio; et in omnibus peccantibus pecco, quando eos quos scio peccasse sive peccare, quadam crudelis animi malignitate non increpo”, ŹM 17, 224-225: „Jeżeli widzę popełniającego grzech i nie tylko go nie karcę, ale zezwalam na jego grzech, staję się współuczestnikiem jego potępienia".

${ }^{50}$ Teksty synodalnych Ordines zawierały również nawiązania do listów Hieronima (ok. 331419), Augustyna (354-430) i Leona Wielkiego († 461). Nie brakowało także odwołań do nauczania Grzegorza Wielkiego (540-604). 
trudności w próbie prześledzenia dokładniejszej recepcji tego dzieła na terenie państwa Franków. Wskazówką, która pozwala założyć, że Dhuoda znała regułę zakonną przygotowaną przez biskupa Hippony, jest przywołana w prologu do Liber manualis augustyńska metafora zwierciadła. Naśladując retorykę Augustyna, autorka starała się przybliżyć cel i przesłanie zadedykowanej Wilhelmowi księgi. Tak jak wspólnota zakonna miała przeglądać się w rozdziałach Reguły, tak młodociany syn Dhuody powinien zatrzymać swój wzrok na Podręczniku, który przygotowała dla niego matka:

„Nawet jeżeli masz wiele ksiąg, niechaj miłym się dla ciebie stanie czytanie mojego dziełka i - z pomocą wszechmogącego Boga - obyś dla własnego dobra zrozumiał jego treść. Odnajdziesz w nim wszystko cokolwiek chciałbyś poznać; znajdziesz także i zwierciadło, w którym bez wątpienia będziesz mógł dostrzec zbawienie swojej duszy, obyś mógł znaleźć upodobanie nie tylko w życiu doczesnym, lecz przede wszystkim w Tym, który ciebie ulepił z prochu" 51 .

Tę samą wykładnię znajdziemy w monastycznej regule Augustyna, który zamykając dzieło polecił współbraciom, aby nie ustawali w ciagłym przeglądaniu się w nim, tak samo jak w zwierciadle:

„Abyście jednak nie zaniechali czegoś przez niedbalstwo, niech ta książeczka będzie czytana raz na tydzień dla przeglądania się w niej jak w zwierciadle. A odkrywszy to, co zostało w niej napisane, składajcie dzięki Bogu szczodrobliwemu, dawcy wszystkiego" 52 .

Należy zauważyć, że biskup Hippony w odniesieniu do Reguły użył deminutywnej formuły - książeczka. Dhuoda w paralelny sposób swój Podręcznik określiła jako dziełko. Celowo zmierzała też do wypełnienia go monastyczny-

${ }^{51}$ Dhuoda, Liber manualis, Prologus, SCh 225, 80-82: „Licet sint tibi multa adcrescentium librorum volumina, hoc opusculum meum tibi placeat frequenter legere, et cum adiutorio omnipotentis Dei utiliter valeas intelligere. Invenies in eo quidquid in brevi cognoscere malis; invenies etiam et speculum in quo salutem animae tuae indubitanter possis conspicere, ut non solum saeculo, sed ei per omnia possis placere qui te formavit ex limo". W innym miejscu Prologu Dhuoda w ten sposób nakreśliła przed Wilhelmem koncepcję swojego podręcznika: „in speculis mulierum demonstratio apparere soleat vultu, ut sordida extergant, exhibentesque nitida, suis in saeculo satagunt placere maritis, ita te obto ut, inter mundanas et saeculares actionum turmas oppressus, hunc libellum a me tibi directum frequenter legere, et, ob memoriam mei, velut in speculis atque tabulis ioco, ita non negligas" (tamże, SCh 225, 80), ,podobnie jak niektóre niewiasty mają zwyczaj przyglądać się swemu odbiciu w zwierciadłach, aby usunąć to, co szpeci, i przywrócić im piękno, troszczą się, żeby w życiu doczesnym podobać się swym mężom, tak i ciebie proszę, abyś przytłoczony ogromem obowiązków świeckich, nie zaniedbywał często czytywania tej niewielkiej książeczki, którą ci posyłam, przez pamięć o mnie, by stała się dla ciebie niczym te zwierciadła".

${ }^{52}$ Augustinus, Regula ad servos Dei VIII 2, PL 32, 1381: „Ut autem vos in hoc libello tanquam in speculo possitis inspicere, ne per oblivionem aliquid negligatis, semel in septimana vobis legatur. Et ubi vos inveneritis ea quae scripta sunt facientes, agite gratias Domino bonorum omnium largitori", thum. M. Starowieyski: Reguła św. Augustyna, w: Starożytne reguły zakonne, PSP 26, Warszawa 1980, 100. 
mi ideałami. Chciała, aby jej świecki traktat, zbliżył się w swym charakterze do zakonnych reguł i był - na ich podobieństwo - ideowym manifestem jedności i braterskiej miłości w chrześcijańskiej wspólnocie.

\section{Przystowia mędrców jako narzędzie argumentacji w zwierciadle dla}

Wilhelma. Kolejnym źródłem należącym do grupy monastycznych, pod którego wpływem pozostawała Dhuoda komponując podręcznik dla Wilhelma, były tzw. apoftegmaty ojców - Verba seniorum - czyli zbiór sentencji oraz budujących przykładów z życia sławnych mnichów ${ }^{53}$. Autorka odniosła się do Przysłów mędrców tylko w jednym miejscu swoich rozważań. Wprowadzony przez nią passus, choć daleki od literalności i najprawdopodobniej przywołany z pamięci, nie budzi jednak najmniejszych zastrzeżeń co do swojej proweniencji. Fragment zainspirowany lekturą Verba seniorum odnajdujemy w ósmej księdze Podręcznika, która wypełniona została matczynymi pouczeniami na temat modlitwy. Księżna z Uzès przekonywała Wilhelma, jak ważna jest codzienna modlitwa w intencji kleru, króla, ojca, a także wszystkich bliskich zmarłych. Nie powinien on przy tym zapominać także o chrześcijanach, którzy zbłądzili i zaparli się jedynej, słusznej wiary. Dhuoda nie miała wątpliwości, że jeżeli nie zdążą oni odkupić przed śmiercią swoich win, to spotka ich okrutna kara. Chcąc w wymowny sposób odmalować przed synem rozmiar cierpień obecnych w otchłani czyśćca i piekła, przytoczyła dialog, który pewien ascetyczny opat miał niegdyś odbyć z tajemniczym głosem pokutującego grzesznika:

„Wtedy starzec rzekł: «Jakiego rodzaju jest wasza męka?» Odpowiedział mu głos: «Jak bardzo niebo jest oddalone od ziemi, tak wielki ogień jest ponad moją głową i pod moimi stopami. Ja zaś z podobnymi do mnie stoimy w środku. Ci natomiast, o których mówiłem, pod naszymi stopami w największych głębokościach piekła odczuwają najokrutniejsze tortury». Wtedy starzec zaczął z wyciem lamentować: «Ach biada dniu, w którym człowiek przekroczył Boże przykazania» - później zaś oddalił się"s4.

${ }^{53}$ Zbiór powstał pod koniec $\mathrm{V}$ w. jako dzieło nieznanego zbieracza. Zachował się w różnych układach opracowaniach i przekładach. Por. C.V. Manzanares, Pisarze wczesnochrześcijańscy I-VII w., tłum. E. Burska, Warszawa 2001, 22. W połowie VI w. łaciński przekład apoftegmatów został przygotowany przez dwóch przyszłych papieży - diakona rzymskiego Pelagiusza (papież w latach 556-561) oraz subdiakona Jana (znanego później jako Jan III, tron apostolski objął po śmierci Pelagiusza 561-574). Przysłowia mędrców znalazły się w XVII w. we wspólnej kolekcji Vitae patrum, stanowiącej encyklopedyczny zbiór pism hagiograficznych poświęconych Ojcom pustyni. Kolekcję zredagował bollandysta Heribert Rosweyde (1569-1629). Księga szósta i siódma wspomnianego dzieła zawierała zebrane Verba seniorum anonimowych autorów greckich. Por. H. Delehaye, The work of the Bollandists through three centuries, 1615-1915, Princeton 1922, 17-20.

${ }^{54}$ Dhuoda, Liber manualis VIII 13, SCh 225, 316: „Tunc dixit senex: «Et qualis est poena vestra?». Respondit vox: «Quantum distat coelum a terra, tantum est ignis super caput meum et subtus pedes meos. Ego autem, cum meis similibus in medio stamus. Hi autem quos dixi, sub- 
Przywołany przez autorkę fragment w wielu miejscach koresponduje z dyskursem, który pojawił się w zbiorze Apoftegmatów Ojców pustyni i miał miejsce pomiędzy abbą Makarym i znalezioną przez niego czaszką pogańskiego kapłana:

„«Na czym polega ta pociecha?» - spytał starzec. Czaszka odpowiedziała: «Jak wysoko niebo wznosi się nad ziemią, tak wielki ogień płonie pod naszymi stopami i nad głowami. Kiedy tak stoimy wśród ognia, nie jest możliwe, aby ktoś mógł spojrzeć w twarz swemu sąsiadowi». Starzec rzekł z płaczem: «Przeklęty dzień, w którym zrodził się człowiek, jeśli na tym polega pociecha w mękach». Pytał on dalej: «Czy są gorsze męki od tych?». Czaszka odrzekła: «Sroższa kara znajduje się pod nami». «Kto ją cierpi?» - zapytał starzec. Czaszka odparła: «My, którzy nie znaliśmy Boga, otrzymujemy trochę litości, ci natomiast, którzy poznawszy Boga odrzucili go i nie czynili Jego woli, ci właśnie znajdują się pod nami» ${ }^{55}$.

Zauważamy, że dialog włączony przez Dhuodę do jej eschatologicznych rozważań odbiega od oryginalnej wersji, która znalazła się w znanym zbiorze przysłów Ojców pustyni. Należy podkreślić także, że autorka nie podała ani imienia wspomnianego starca, ani także właściciela tajemniczego głosu, który w Apoftegmatach należał do kapłana czczącego pogańskie bożki. Można założyć, że był to zabieg celowy. Karolińska uczona po raz kolejny - w odniesieniu do znanych jej fragmentów źródłowych - nie zmierzała do ich literalnego przedstawienia. Jej celem było jedynie wykorzystanie znanych motywów, a także kaznodziejskich środków wyrazu, które pochodziły z monastycznych pism. Znamiennym dla retoryki Liber manualis było swobodne podejście do wszystkich tekstów źródłowych, które interpretowane były przez uczoną ze sporą dawką samodzielności i dowolności. Smiałe i nowatorskie komentarze Dhuody nigdy jednak nie były na tyle ryzykowne, aby móc posądzić je o daleką od dogmatów aberrację.

tus pedes nostros in profundissimum inferni immanissima sentiunt tormenta». Tunc senex cum rugitu coepit lamentare, dicens: «Vae diei in quo homo praeceptum Domini transgressus est», et tunc recessit".

${ }_{55}$ Apophtegmata Patrum, Collectio systematica (Verba seniorum) III 16, PL 73, 1013C-D: „Dicit ei senex: «Et quae est ipsa consolatio?» Respondit illud caput: «Quantum distat caelum a terra, tantum est ignis sub pedibus nostris, et super caput nostrum. Stantibus ergo nobis in medio ignis, non est ut quis facie ad faciem videat proximum suum». Ait ergo senex cum fletu: «Vae illi diei, in qua natus est homo, si haec est consolatio supplicii». Rursum dixit senex: «Est pejus tormentum ab his?» Respondit caput illud: «Major poena subtus nos est». Dixit ei senex: «Et qui sunt in ipsa?» Dicit ei caput illud: «Nos qui ignoravimus Deum, vel ad modicum habemus aliquid misericordiae; hi vero qui cognoverunt Deum, et negaverunt eum, nec fecerunt voluntatem ejus, hi sunt subtus nos»», thum. M. Kozera: Apoftegmaty Ojców pustyni, t. 2. Kolekcja systematyczna XX 16, ŹM 9, Kraków 1995, 338-339. 
Zwierciadłowe dzieło markizy z Septymanii wpisuje się w upowszechniany w okresie rządów Ludwika Pobożnego program reformy życia religijnego. Można zatem wnioskować, że autorka - w zupełnie przemyślany sposób - narrację swą zbudowała na monastycznej i ascetycznej myśli autorów wczesnego chrześcijaństwa, która obecna też była w ówczesnej debacie synodalnej. Wyraźnie więc daje się zauważyć wszechobecny w traktacie duch zakonny. Mądrość Ojców uczona wielokrotnie pogłębiła jednak o aluzje oryginalne, ale nie ryzykowne. Znane fragmenty źródłowe często stawały się punktem wyjścia do podjętych przez nią rozważań. Rzadko przytaczała je jednak literalnie. Nie koncentrowała się także na doniosłym anonsowaniu cytowanych autorytetów. Przyjętą przez Dhuodę metodą twórczą stała się wszechobecna parafraza. Swobodne i dalekie od dosłowności traktowanie źródłowych tekstów może wskazywać jednak tylko na szczątkową ich znajomość. Karolińska pisarka mogła posiadać liczne florilegia ilustrujące określone tematy i doktryny. Nie zmienia to jednak faktu, że należała ona do nielicznego grona ponadprzeciętnie wykształconych kobiet swojego wieku. Wykazała się także niezwykłą wręcz znajomością oraz świadomością realiów politycznych i społecznych, które w IX w. dotknęły karolińskie imperium.

\author{
THE RECEPTION OF ASCETIC AND MONASTIC SOURCES \\ IN DHUODA'S OF SEPTIMANIA (C. 803-843) LIBER MANUALIS
}

(Summary)

The analysis of monastic and ascetic sources concluded in Liber manualis is the main goal of this article. The author is trying to systematize borrowings which Carolingian scientist quoted or paraphrased in her own treaty. The deep exploration of mentioned quote will allow us to determine a compilation and interpretation method which accompany to early Middle Ages scientist. Above and beyond it will let us to ask some research questions about intellectual formation of marchioness from Uzès, her access to tomes, creative awareness and orientation in political and religious changes taking place in a Country.

Key words: Dhuoda of Septimania, Liber manualis, Carolingian literature, Carolingian revival, monasticism in $9^{\text {th }}$ century.

Słowa kluczowe: Dhuoda z Septymanii, Liber manualis, literatura karolińska, renesans karoliński, monastycyzm w IX wieku. 


\section{BIBLIOGRAFIA}

\section{Źródła}

Apophtegmata Patrum, Collectio systematica (Verba seniorum), PL 73, 855-1062, tłum. M. Kozera: Apoftegmaty Ojców pustyni, t. 2. Kolekcja systematyczna, ŹM 9, Kraków 1995.

Augustinus, Regula ad servos Dei, PL 32, 1377-1381, tłum. M. Starowieyski: Reguła św. Augustyna, w: Starożytne reguły zakonne, PSP 26, Warszawa 1980, 93-102.

Benedictus, Regula, ed. P.U. Faust: Die Benediktsregel (Lateinisch/Deutsch), Stuttgart 2009, tłum. A. Świderkówna: Święty Benedykt z Nursji, Reguła, Kraków 2010.

Dhuoda, Liber manualis Dhuodane quem ad filium suum transmisit Wilhelmum, ed. P. Riché, SCh 225, Paris 1997.

Institutio sanctimonialium Aquisgranensis (816), ed. A. Werminghoff, MGH, Concilia 2/1, Hannover 1908, 421-456.

Isidorus Hispalensis, Etymologiarum libri XX, PL 82, 9-728.

Julianus Pomerius, De vita contemplativa, PL 59, 415-520, thum. A. Żurek: Julian Pomeriusz, O życiu kontemplacyjnym, ŹM 17, Kraków 1998.

\section{Opracowania}

Anton H.H., Fürstenspiegel des Frühen und Hohen Mittelalters, Darmstadt 2006.

ANTON H.H., Fürstenspiegel und Herrscherethos in der Karolingerzeit, Bonn 1968.

AuERBACH E., Język literacki i jego odbiorcy w późnym antyku łacińskim i średniowieczu, tłum. R. Urbański, Kraków 2006.

Cherewatuk K., Speculum matris: Duoda's Manual, „Florilegium” 10 (1988-1991) 49-64.

Claussen M.A., Fathers of Power and Mothers of Authority: Dhuoda and the Liber manualis, „French Historical Studies” 19 (1996) nr 3, 785-809.

Delehaye H., The work of the Bollandists through three centuries, 1615-1915, Princeton 1922.

Dyвsкi H., Modlitwa w ujęciu Jana Kasjana, VoxP 36-37 (1999) t. 19, 335-348.

FAŁKowsKi W., Karolińskie zwierciadło władcy - powstanie gatunku, w: Europa barbarica, Europa christiana, red. R. Michałowski, Warszawa 2008.

LE JAN R., Dhuoda ou l'opportunité du discours féminin, w: Agire da donna. Modelli e pratiche di rappresentazione (secoli VI-X), ed. C. La Rocca, Turnhout 2007.

Manzanares C.V., Pisarze wczesnochrześcijańscy I-VII w., thum. E. Burska, Warszawa 2001.

Mayeski M.A., Dhuoda. Ninth Century Mother and Theologian, Scranton 1995.

McKitterick R., Królestwa Karolingów - władza, konflikty, kultura, tłum. B. Hlebowicz - M. Wilk, Warszawa 2013.

McKitterick R., The Carolingians and the Written Word, New York, Cambridge 1989.

Meyers J., Dhuoda et la justice d'après son Liber Manualis (IX siècle), „Cachiers de Recherches Médiévales et Humanistes" 25 (2013) 451-462.

Nelson J., Gendering Courts in the Early Medieval West, w: Gender in the Early Medieval World. East and West, 300-900, ed. L. Brubaker - J.H.M. Smith, Cambridge 2004.

Prinz F., Niemcy - narodziny państwa. Celtowie, Rzymianie, Germanie, thum. D. Fałkowska, Warszawa 2007.

RYś J., Wychowanie moralne $w$ rodzinie arystokratycznej $w$ czasach karolińskich $w$ świetle Podrecznika dla syna Dhuody, „Rocznik Naukowo-Dydaktyczny WSP w Krakowie" (1999) z. 201, 12-24.

Thiebaux M., Dhuoda, Handbook for her Warrior Son. Liber Manualis, Cambridge 1998. 
